\title{
Degradation of dietary fibre from 'Gari' by faecal bacteria and bacteria extracellular polysaccharidases
}

\author{
Uzomah Abimbola \\ Department of Food Science and Technology, \\ Federal University of Technology, Owerri, Imo State, Nigeria \\ Address for Correspondence Email: abimuzomah@yahoo.com
}

\begin{abstract}
Dietary fibre (soluble and insoluble fibre) was extracted from 'gari' (a fermented cassava product). The 'gari' fibre was subjected to degradation by faecal microflora and the microbial extracellular enzymes obtained from six clinically healthy adults (S1-S6). Other common components of dietary fibre namely starch, xylan, carboxymethlcellulose (CMC) and polygalacturonic acid (PGA) were also treated with the extracellular enzymes. Degradation of the fibre was monitored by measuring the reducing sugar groups in the reaction mixture. Enzyme activity was expressed as units/mg protein. The results obtained demonstrated that the human faecal microflora

sugars ranged from 1.5-4.5 mg/ml. Degradation rate varied considerably between the six individuals. Effect of the faecal extracellular enzyme on the fibre indicated a high concentration of the starch hydrolyzing enzyme, amylase. For all the six subjects the activities were (U/mg protein): amylase 2.5-5.4; xylanase 0.8-3.6 and pectinase 0.0882.1. Cellulases activity detected in only one of the subjects was $0.76 \mathrm{U} / \mathrm{mg}$ protein. The results of this study suggested that the fibre from gari may be rich in starch component resistant to the action of amylase and amyloglucosidase and this component were readily degraded by enzyme from the faecal microflora.
\end{abstract} were able to degrade the gari fibre considerably within 24 $\mathrm{hr}$ of incubation. The values obtained for the reducing

\section{INTRODUCTION}

$\mathrm{T}$ The fibre content of the human food has been considered to be a significant factor which influences the physiology of the bowel and that of the large intestine. One major problem in the analysis of dietary fibre is the manner in which the fibre is expressed. Studies based on crude fibre measurements are usually much lower than cell wall values because of the removal of hemicellulose and lignin. Consequently analysis based on crude fibre does not rank food in the same order as dietary fibre. The original description of dietary fibre by Trowel (1972) was "that portion of food which is derived from cellular walls of plants which is digested very
Keywords: Dietary fibre, gari, faecal bacteria, extracellular polysacharidases. poorly by human beings". According to Englyst and Cummings (1990) and Englyst et al, (1992) amongst others, this definition has been found to be only a physiological concept. Of recent dietary fibre has been considered to be composed of non-starch polysaccharides plus lignin, resistant oligosaccharide and resistant starch (Englyst and Cummings, 1987; Englyst et al., 1993). The resistant starch consist of physically trapped starch (RS1), resistant starch granules (RS2) and retrograded starch (RS3) (Bright-See and Jazmaji, 1991; Muir et al., 1993).

The most important property of fibre is its ability to serve as a substrate for microbial gastrointestinal fermentation and this ability also 
depends on the amount and type of substrate available (Cummings and MacFarlane, 1997). The degradation of dietary fibre by bacteria in the large intestine by persons consuming the Western diet has been extensively studied (Englyst and Cummings, 1987; Wedekind et al., 1988; Steven et al., 1988; Montgomery, 1988; Englyst et al., 1988; Bingham et al., 1990; Anderson and Bridges, 1993; Muir et al., 1993). They found that there were substantial quantities of undigested food residues reaching the large intestine most of which are digested by the gut microflora. Their findings also elaborated on the protective nature of these fibre rich diet against certain heart and colorectal diseases.

Most of the foods consumed in Nigeria are rich sources of these fibre components but literature on this is scanty (Adams-Campbell et al., 1993). Studies where available were more on crude fibre analysis which does not have much correlation with the fibre component fermented by the gut microflora (Adamson, 1985; Adekunle and Funmilayo 1986). Gari a fermented cassava product is a staple food for most people in the Eastern Sates of Nigeria. It is known to be rich in starch but the unit operations involved in processing the raw cassava tuber to a partially dextrinised and gelatinized product known as gari may have resulted in the production of resistant starches that could not be readily digested by the gastric enzyme but serves as substrates for the gut microflora. This study therefore aimed at investigating degradation of the fibre extracted from gari by the faecal bacteria. The effect of the faecal extracellular polysaccharidases on the fibre and some other fibre components common in foods will also be investigated.

\section{MATERIALS AND METHODS \\ Dietary Fibre Extraction}

A modified method of Theander and Westerlund (1986) and Englyst et al., (1982) was employed. The method consists of gelatinization of starch followed by enzyme hydrolysis of the gelatinized starch. About $3 \mathrm{~g}$ of the gari sample was extracted in 50-ml glass centrifuge tube. Prior to the dietary fibre extraction, the free sugars were extracted using $80 \%$ ethanol (3x $75 \mathrm{ml} ; 15 \mathrm{~min}$ ) under reflux. Afterwards, it was decanted and the insoluble residue was dried under a stream of warm air, cooled and a portion was transferred to the glass centrifuge tube for the extraction of the dietary fibre constituents as follows: Two grammes of the dried residue were suspended in $10 \mathrm{ml}$ of $0.1 \mathrm{M}$ acetate buffer solution ( $\mathrm{pH}$ 5.2). The buffer contained $4 \mathrm{mM}$ calcium chloride to stabilize and activate the enzymes. A magnetic stirring bar was added and the tube was placed in a water bath for $1 \mathrm{hr}$, stirring continuously to gelatinize the starch. Heat stable amylase, Termamyl 120L (0.2 $\mathrm{ml})$ was added to the gelatinized samples and incubated at $1000 \mathrm{C}$ for $15 \mathrm{~min}$ with continuous stirring. The tubes were removed from the water bath and $40 \mathrm{ml}$ of absolute ethanol was added. The tubes were then placed in an icewater bath for $30 \mathrm{~min}$ to precipitate any solubilized dietary fibre components. The precipitate was pelleted by centrifugation at 2000 $\mathrm{x} g$ for $15 \mathrm{~min}$ at ambient temperature. The supernatant containing the soluble sugars or hydrolyzed starch was removed by aspiration and was discarded. The pellet was then placed in 8 $\mathrm{ml}$ of $0.1 \mathrm{M}$ acetate buffer $\mathrm{pH} 4.5$ and $0.1 \mathrm{ml}$ of amyloglucosidase suspension was added, thoroughly mixed and incubated at $370 \mathrm{C}$ for 35 min. The residue after digestion was recovered by ethanol precipitation and centrifugation as previously described the supernatant was discarded as above. The residue was dried at 100 $0 \mathrm{C}$. The residue served as the total dietary fibre (soluble and insoluble) obtained from gari and referred to as gari fibre in this study. 


\section{Subjects}

Six clinically healthy persons ages 25 to 40 years, participated in the study. There was no controlled diet they were used, based on their usual food habit.

\section{Stool Samples}

Stool samples labeled S1, S2, S3, S4, S5 and S6 were collected in a double layered polyethylene bags which were chilled immediately in an insulated ice-box containing two packs of ice blocks

The samples were transported to the laboratory within $2 \mathrm{hr}$ of collection. They were kneaded to ensure thorough mixing.

\section{Preparation of Faecal Isolates}

Anaerobic Dilution Solution (ADS) used in the study contained the following ingredients per Litre of the solution: Mineral solution 1, $33 \mathrm{ml}$; mineral solution $2,75 \mathrm{ml}$ and resazurin $(0.1 \%$, w/v), $1.0 \mathrm{ml}$. Mineral solution 1 contained $8 \mathrm{~g} / \mathrm{lit}$ $\mathrm{K}_{2} \mathrm{HPO}_{4}$ in distilled water. Mineral solution 2 contained the following in $\mathrm{g} / \mathrm{lit} ; \mathrm{K}_{2} \mathrm{HPO}_{4}, 4.8$; $\mathrm{NaCl}, 12 ;\left(\mathrm{NH}^{4}\right)_{2} \mathrm{SO}_{4}, 12 ; \mathrm{CaCl}_{2} \cdot 6 \mathrm{H}_{2}{ }^{\mathrm{O}} 2.4$; $\mathrm{MgSO}_{4}, 2.5$. The salts were dissolved separately in $200 \mathrm{ml}$ distilled water, mixed in the order given and the volume made up to a litre. The solutions for the ADS were mixed, boiled under carbon dioxide and autoclaved at $1210^{\circ}$ for $15 \mathrm{~min}$. The solution of sodium thioglycollate, a reducing agent, $(2 \% \mathrm{v} / \mathrm{v})$ was added after autoclaving (Ljungdahl and Wiegel, 1986). One gram of the faecal material was transferred into a tube containing $9 \mathrm{ml}$ of ADS. The slurry so obtained was used as the stock solution. Nine milliliters of Schaedler's broth (Oxoid) was inoculated with $1 \mathrm{ml}$ of the faecal slurry (stock solution) in a glass bottle (bijoux bottle) and incubated for 2 days at $37^{\circ} \mathrm{C}$. The bacterial isolates so obtained were used to seed the supplemented medium.

\section{Preparation of Supplemented Medium}

Basal supplemented medium 10 (BSM10) was prepared as described by Caldwell and Bryant (1966) but without the addition of the carbohydrates and volatile acids. The medium was supplemented with liver extract and chicken faecal extract (Barnes and Impey, 1974) and was prepared as follows: Amounts in g/litre; yeast extract, 0.5 ; trypticase, 2.0 . Amounts in $\mathrm{ml} /$ litre: mineral solution $1,37.5$; mineral solution 2, 37.5; haemin, $(0.1 \mathrm{ml} / \mathrm{ml}), 10$; resazurin $(0.1 \%, \mathrm{w} / \mathrm{v})$, 1 ; liver extract $5 \%(\mathrm{v} / \mathrm{v})$; chicken faecal extract, $10 \%(\mathrm{v} / \mathrm{v})$. Carbohydrate content was $0.1 \%$ (w/ v) of gari fibre. The control sample did not contain any carbohydrate. The mixture was autoclaved $\left(121^{\circ} \mathrm{C}, 15 \mathrm{~min}\right)$

The bacterial isolates grown in Schaedler's broth (SB, Oxoid) $(1 \mathrm{ml})$ were used to seed the supplemented medium. Test cultures were incubated at $37^{\circ} \mathrm{C}$ at $0,12,24,36,48,60$ and 72 h. The cultures were each centrifuged and the reducing sugars produced were determined by the method of Miller (1959). In each of the stages described above strict anaerobic techniques were maintained and all manipulations were carried out under a stream of carbon dioxide (Ljungdahl and Wiegel, 1986).

\section{Extraction of Enzymes}

Stool samples were homogenized in a chilled $50 \mathrm{mM}$ potassium phosphate buffer $\mathrm{pH}$ 7.0 (1:1). Chilled aliquots were centrifuged at $2500 \mathrm{x} \mathrm{g}$ twice for $30 \mathrm{~min}$. The supernatant fluids were concentrated at $4^{\circ} \mathrm{C}$ using polyethylene glycol (PEG, 6,000). A suitable quantity of PEG was placed in a cellulose dialysis Visking tubing size 2-18/32 (Hedigell International Ltd. England). The bag was placed in the supernatant fluid and kept at $4^{\circ} \mathrm{C}$ for $12 \mathrm{~h}$ to concentrate the supernatant. The concentrated fraction was used as the extracellular enzyme source. 


\section{Enzyme Assays}

The enzymes that catalyze the depolymerization of each of these substrates; soluble starch, xylan, carboxymethylcellulose (CMC) and polygalacturonic acid (PGA) were assayed separately by measuring the release of reducing groups from these substrates during the incubation of the enzyme-substrate mixtures. The enzyme reaction mixture contained $0.5 \mathrm{ml}$ of the concentrated enzyme fraction, $4.5 \mathrm{ml}$ of $1 \%$ substrate (soluble starch, xylan, CMC and PGA) dissolved in $50 \mathrm{mM} \mathrm{Na-Acetate} \mathrm{buffer} \mathrm{pH}$ 5.5. The final $\mathrm{pH}$ of the mixture was 6.8. The mixture was incubated at $37^{\circ} \mathrm{C}$ for $1 \mathrm{~h}$. The reaction was stopped by heating at $100{ }^{\circ} \mathrm{C}$ for 5 min. Aliquot $(1 \mathrm{ml})$ was assayed for reducing sugars by the dinitrosalicylic acid (DNS) method of Miller (1959) using glucose as a standard. The amount of reducing groups in the reaction mixture was determined colorimetrically with a UV/Visible spectrophotometer (SP-600). Zero time reactions were used as controls. Enzyme activity was expressed as specific activities (units/mg protein). One enzyme unit was equivalent to ìg reducing sugar formed/min.

The effects of the microbial exracellular enzymes on the gari fibre were also studied. Pooled fractions of the concentrated supernatant obtained above (S1, S2, S3 as one fraction and S4, S5, S6 as the second fraction) were added to different concentrations $(0.1,0.25,0.5,0.75$ and $0.1 \%$ w/ v) of gari fibre. The amount of reducing sugars released and the enzyme activities were determined..

\section{Determination of Reducing Sugars}

The DNS reagent was prepared by mixing Reagents A and B until all the compounds dissolved. Reagent A contained $225 \mathrm{~g}$ of potassium sodium tartarate in a mixture of 800 $\mathrm{ml}$ of $1 \%$ dinitrosalicylic acid and $300 \mathrm{ml} \mathrm{4.5 \%}$ $\mathrm{NaOH}$. Reagent B contained $6.9 \mathrm{~g}$ of sodium metabisulphite dissolved in $69 \mathrm{ml}$ of Reagent $\mathrm{C}$. Reagent $\mathrm{C}$ was prepared by mixing a solution of
$22 \mathrm{ml} 10 \% \mathrm{NaOH}$ and $10 \mathrm{~g}$ crystalline phenol made up to $100 \mathrm{ml}$ with distilled water. Three milliliters of the DNS reagent was added to $1 \mathrm{ml}$ of the test sample. The mixture was boiled for $15 \mathrm{~min}$. the resulting color was measured at 540 $\mathrm{nm}$ on a UV/Visible spectrophotometer. One milliliter of distilled water was used for the blank. Determination of Protein in Enzyme Fraction

The protein content of the crude enzyme was determined by the method of Lowry et al., (1951). Ten milligram's of Bovin serum albumin (BSA) in $50 \mathrm{ml}$ of distilled water was used as the standard stock reagent composition. From this stock solution, serial dilutions with appropriate volume of water to give concentration ranging from 0.01 to $0.2 \mathrm{mg} / \mathrm{ml}$ were prepared. One milliliters of freshly prepared alkaline copper solution was added to $5 \mathrm{ml}$ of the test solution and allowed to stand at room temperature for at least $10 \mathrm{~min}, 0.5 \mathrm{ml}$ of the diluted Folin- $\mathrm{C}$ reagent was added rapidly, and then mixed immediately. After $30 \mathrm{~min}$, the absorbance against the appropriate blank was read at $750 \mathrm{~nm}$. Protein concentration of the test solution was read from the standard curve of Bovine Serum Albumin (BSA, Sigma, USA). .The alkaline copper solution contained $50 \mathrm{ml}$ of $2 \% \mathrm{Na}_{2} \mathrm{CO}_{3}$ in $0.1 \mathrm{M} \mathrm{NaOH}$ added to $1 \mathrm{ml}$ of $0.5 \% \mathrm{CuSO}_{4} .5 \mathrm{H} 20$ (the solution of the $\mathrm{CuSO}_{4} .5 \mathrm{H}_{2} 0$ was made in $1 \%$ sodium potassium tartarate).

\section{RESULTS AND DISCUSSION}

The ability of faecal micro-organism to degrade the gari fibre was monitored by measuring the reducing sugars released during the incubation period. The results are presented in Fig. 1. The breakdown of the fibre varied considerably between the subjects. In $\mathrm{S} 1$ and $\mathrm{S} 2$ reducing sugars increased steadily within the first $24 \mathrm{~h}$ to maximum values of 3.8 and $3.4 \mathrm{mg} / \mathrm{ml}$ respectively. A steady increase was also observed for S4 till the 48th h while S5 
reached the maximum value of $2.7 \mathrm{mg} / \mathrm{ml}$ in 36 h. Production of the reducing sugars was most rapid in S3 where the highest value of $4.5 \mathrm{mg} / \mathrm{ml}$ was recorded within $12 \mathrm{~h}$ (Fig. 1). The result in Table 1 show that polysaccharide degrading enzymes were present in the faeces of the subjects. Activities of the enzyme degrading starch, xylan and pectin were detectable (Table 1). Specific activities for the starch degrading enzyme ranged from 2.5 to $5.4 \mathrm{U} / \mathrm{mg}$ protein; 0.8 to $3.6 \mathrm{U} / \mathrm{mg}$ protein for xylanase and 0.088 to $2.1 \mathrm{U} / \mathrm{mg}$ protein for pectinase. There was no cellulase activity in five of the subjects examined, only one of the subjects showed an activity of $0.76 \mathrm{U} / \mathrm{mg}$ protein. This agrees with the findings of Stevens et al, (1988). They reported that large proportions of pectic polysaccharide are readily degraded by bacteria of the human colon but the xyloglucan and cellulose are less readily degraded. The high activities of the starch degrading enzyme suggest the dominant presence of its polymer in the fibre. Similar result was reported by MacFarlane and Englyst (1986). These workers demonstrated that starch degradation by colon bacteria was complete within $10 \mathrm{~h}$ of incubation. They concluded that the gut microflora probably played a major part in the starch break down in the colon and the bacterial amylase activity in faeces was primarily cell-based.

There are numbers of physiological and biochemical factors affecting fermentability. The fermentable portion of fibre resides primarily in the polysaccharide fractions. Other factors include the particle size of the foodstuffs, chemical composition of the polymers and the effect of food processing such as cooking, cooling, drying and freezing. The fermentability of the gari fibre investigated in this study is therefore governed by these factors. According to Fuwa et al., (1980) dietary fibre component reaching the colon includes the resistant starch and the dietary gum. Resistant starch is that starch which is resistant to pancreatic enzymes and they are starch present in whole or partly milled grains or seeds such as corn peas, beans and cracked grains. Some resistant raw starch granules are due to changes in starch structure due to retrogradation which renders the starch resistant to pancreatic amylase (Englyst and Cummings, 1990; Englyst et al., 1992).

Processing of the raw cassava tuber to gari involves different stages which include reduction in size, fermentation/dextrinization, partial gelatinization and retrogradation. This probably led to the development of resistant starch and some oligosaccharides may be included in the dietary fibre fraction. The dietary fibre extraction procedure in this study did not include the use of dimethylsulphuroxide (DMSO) or $\mathrm{KOH}$ for the dispersion of resistant starch, hence the gari fibre so obtained included these starches that resist the amylase. Since heat stable amylase was used at $1000 \mathrm{C}$, physically enclosed starch (RS1) and resistant starch granules (RS2) will not be included. Thus suggesting that retrograded amylose (RS3) is the main form of resistant starch left in the gari fibre. Lignin and some other non-starch polysaccharide may also be present. The results of this study tend to confirm those of other workers (Anderson et al., 1981; Englyst and Cummings, 1987). They reported that there are substantial quantities of dietary starch which can resist hydrolysis by pancreatic amylase in the small intestine. MacFarlane and Englyst (1986) also found that there are high levels of amylase activity in human faeces with over $92 \%$ of the activity being extracellular.

Figures 2 and 3 show the effect of the extracellular enzyme activities in the pooled fractions with varying concentrations of the fibre. The activities at the initial stage increased linearly with increasing substrate concentration in the two fractions. In the pooled fraction of 
$\mathrm{S} 1, \mathrm{~S} 2$ and S3. the initial increase in the enzyme activity dropped when the substrate concentration was between $1 \mathrm{mg} / \mathrm{ml}$ and $2 \mathrm{mg} / \mathrm{ml}$, but increased with subsequent increase of the substrate concentration. The S4-S6 fraction behaved differently, after the initial rise in activity, the decrease in activity was between $2.5 \mathrm{mg} / \mathrm{ml}$ and $5 \mathrm{mg} / \mathrm{ml}$ substrate concentration, further increase in substrate concentration did not affect the activity. These discrepancies may be attributed to the source of enzyme which was a crude extract and thus contain some inhibitors. The rate approached a limiting velocity at substrate concentrations as low as 1.0 and $2.5 \mathrm{mg} / \mathrm{ml}$. Generally, the rate of an enzyme catalyzed reaction over a range of substrate concentration gives a rectangular hyperbolic curve, and the enzyme activity reaches a maximum after a certain level of the substrate concentration. When there is an inhibitor in the enzyme-substrate medium, as the case may be in this study, such curves obtained in this study may be expected. The decrease in activities could be attributed to the action of inhibitor in the system. It also follows that subsequent increase in substrate concentration may cause an increase in activity, if it is a non-competitive inhibitor. With a competitive inhibitor increasing substrate concentration does not dissociate the enzymeinhibitor complex. Results thus obtained suggested the presence of inhibitor(s) in the medium. Further studies may be necessary to investigate both the cell associated polysaccharidases and the cell free polysaccharidases in a purified form. For technical reasons it was not possible to study this area, however it is believed that the results of this study will help in the understanding of the nature of the dietary fibre from gari as affected by the gut microflora.

\section{ACKNOWLEDGEMENT}

The author acknowledges the immense contributions of the late Dr C. O. Ofuya of the Department of Microbiology, University of Port Harcourt, Nigeria, who initiated this study and late Dr. E. O. Uche of the College of Medicine, (of the same University ) who was very helpful in the collection of the faecal samples.

\section{REFERENCES}

Adams-Campbell, L. L., Agurs, T. D. and Ukoli, F. A. (1993). Dietary assessment in Nigerian Women: A pilot study. Ethnicity and Disease 3: S62-S66.

Adamson, I. (1985). The dietary fibre of yam and cassava. In: Advances in yam research. (Osuji, G. (ed). Anambra State University of Technology, Nigeria. p 321 - 342 .

Adekunle, O. O. and Fumilayo, J. A. (1986). Acute appendicitis in Nigeria. Journal of Royal College of Surgeons. Edinburgh 31: 102195.

Anderson, J. H., Levine, A. S. and Levitt, M. D. (1981). Incomplete absorption of the carbohydrate in all purpose wheat flour. New England Journal of Medicine 304: 891- 892.

Anderson, J. W. and Bridges, S. R., (1993). Hypercholesterolemia effects of oat bran in humans In: Oat bran, Wood, P. J. (Ed). American Association of Cereal Chemists. St Paul, MN. p. 139.

Barnes, E. A. and Impey, C. S. (1974). The occurrence and properties of uric acid decomposing anaerobic bacteria in the avian caecum. Journal of Applied Bacteriology. 31: 393-409. 
Bingham, S. A., Pett, S and Day, K. C. (1990). NSP intake of a representative sample of a British adults. Journal of Human Nutrition and Dietetics 3: $339-344$

Bright-See, E. and Jazmaji, V. (1991). Estimation of the amount of dietary starch available to different populations. Canadian Journal of Physiology and Pharmacology. 60: 56-59

Caldwell D. R. and Bryant, M. P. (1966). Medium without rumen fluid for non-selective enumeration and isolation of rumen bacteria. Applied Microbiology. 14: 794-813

Cummings, J. H. and MacFarlane, G. T. (1997). The role of internal bacteria in nutrient metabolism. Clinical nutrition, 16: 3-11

Englyst H. N. and Cumminjgs, J. H. (1990). Nonstarch polysacchraride (dietary fibre) and resistant starch. New developments in dietary fiber physiological, physicochemical and analytical aspects. Furda, I. and Brine, C. J. (Eds). Plenum Press, New York and London, p. $205-225$

Englyst H. N., Kingman, S. M. and Cummings, J. H. (1992). Classification and measurement of nutritionally important starch fractions. European Journal of Chemical Nutrition. 4: S33 - S50

Englyst, H. N., Kingman, S. M. and Cummings, J. H. (1993). Resistant Starch: measurement in foods and physiological role in man. In: plant polymeric carbohydrates, Meuser, F.; Manners, D. J. and Seibel, W., (Eds), The Royal Society of Chemistry, Cambridge, U. K. p 137.

Englyst, H. N., Bingham, S. A., Brunswick, S. A., Collinson E. and Cummings, J. H. (1988). Dietary fibre (non-starch polysaccharides) in fruits, vegetables and nuts. Journal of Human Nutrition and Dietetics. 1: $247-286$

Englyst, H. N. and Cummings, J. H. (1987). Resistant starch, a 'new' food component: A classification of starch for nutritional purposes. In: Cereals in a European Context. Morton, I. D. (Ed) Chichester: Ellis Harwood. p 221-233

Fuwa, H., Takaya, T. and Sugimato, Y. (1980).

Degradation of various starch granules by amylases. In: Mechanisms of saccharide polymerization and depolymerization. Marshall, J. J. (ed.) New York: Academic Press. p 73-100

Ljungdahl, L. G. and Wiegel, J. (1986) Working with anaerobic bacteria. In: Manual of Industrial Microbiology and Biotechnology. Demain, A. L. and Solomon, M. A. (Eds) Washington D. C. American Society for Microbiology. p. 84-95.

Lowry, O. H.; Rosebrough, N. J.; Farr, A. L. and Randall, R. J. (1951). Protein measurement with the Folin-Phenol reagent. Journal of Biological Chemistry, 193: 265-275

Macfarlane, G. T. and Englyst, H. N. (1986). Starch utilization by the human large intestinal microflora. Journal of Applied Microbiology. 60: 195-201

Miller, G. L. (1959). Use of dinitrosalicylic acid reagent for determination of reducing sugar. Analytical Chemistry 31: 426-442. 
Montgomery, L. (1988). Isolation of human colonic fibrolytic bacteria. Letters in Applied Microbiology 6: 55-57.

Muir, J. G., Young, G. P., O’Dea, K., CameronSmith, D., Brown, I. E. and Collier, G. R. (1993) Resistant starch - the neglected "dietary fibre"? Implication for health. Dietary fiber bibliography and reviews 1:33

Steven, B. J. H.; Selvendran, R. R.; Bayliss, C. E. and Turner, R (1988). Degradation of cell wall material of apple and wheat bran by human faecal bacteria in vitro. Journal of Science Food and Agriculture 44: 151-166
Theander, O. and Westerlund, E. A (1986) Studies on Dietary fibre 3: Improved proceedings for analysis of dietary fibre. Journal of Agriculture and Food Chemistry. 32: 330 336.

Trowel, H. (1972). Ishemic heart and disease Dietary fibre. American Journal of Clinical Nutrition. 25: 926-932.

Wedekind, K. J., Mansfield, H. R. and Montogomery, L. (1988). Enumeration and isolation of cellulolytic and hemicellulolytic bacteria from human faeces. Applied and Environmental Microbiology 54: 1530-1535.

Table 1: Specific activities of extracellular polysaccharidases in the breakdown of 'gari' fibre

Subject Specific Activity (U/mg protein)

$\begin{array}{lcccc} & \text { Amylase } & \text { Xylanase } & \text { Cellulase } & \text { Pectinase } \\ \text { S1 } & 2.5 & 0.8 & 0.0 & 0.088 \\ \text { S2 } & 2.8 & 3.6 & 0.0 & 0.41 \\ \text { S3 } & 3.6 & 2.3 & 0.0 & 0.097 \\ \text { S4 } & 2.8 & 1.9 & 0.0 & 1.19 \\ \text { S5 } & 3.5 & 0.5 & 0.76 & 1.5 \\ \text { S6 } & 5.4 & 1.3 & 0.0 & 2.1\end{array}$




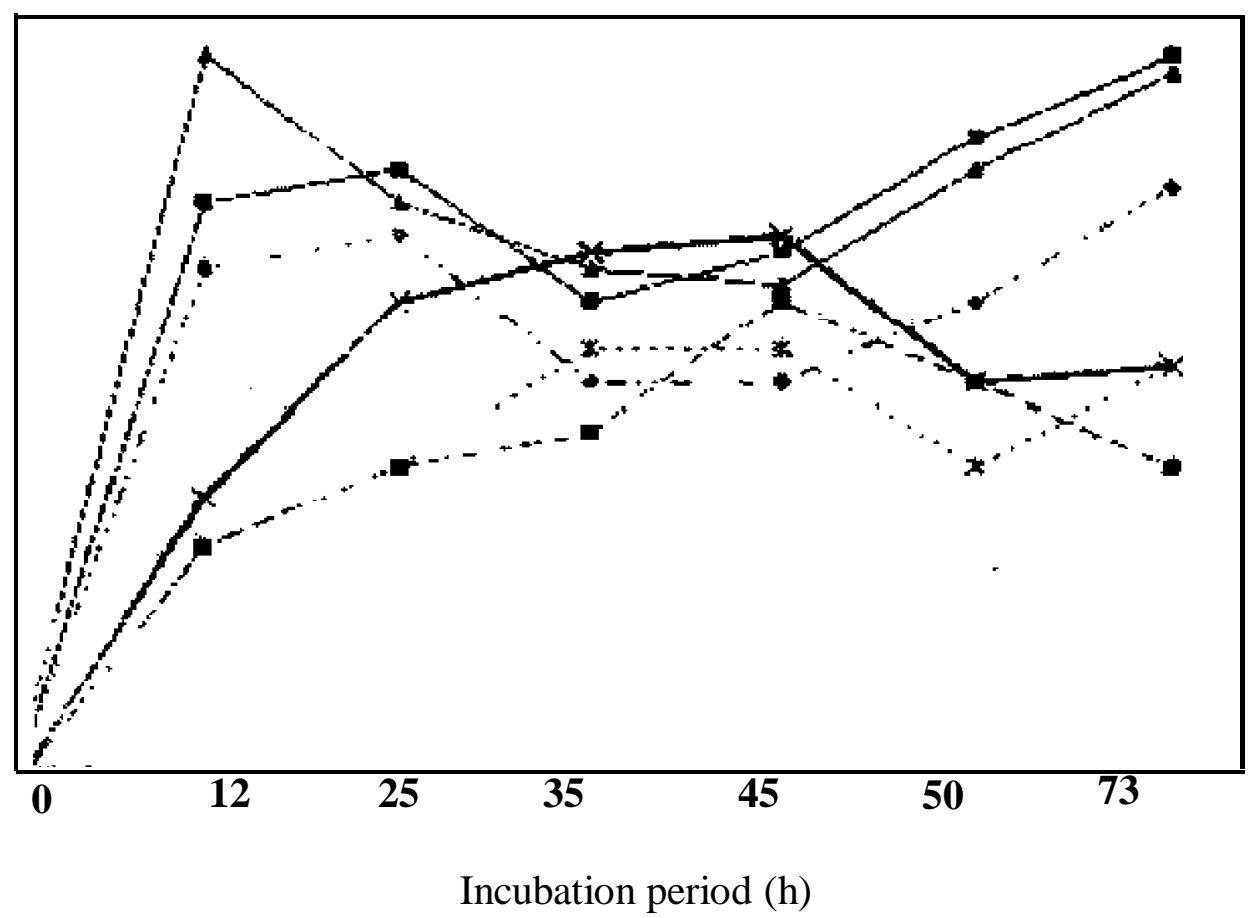

Fig 1. Reducing sugars produced during the degradation of fibre by faecal micro-organisms.

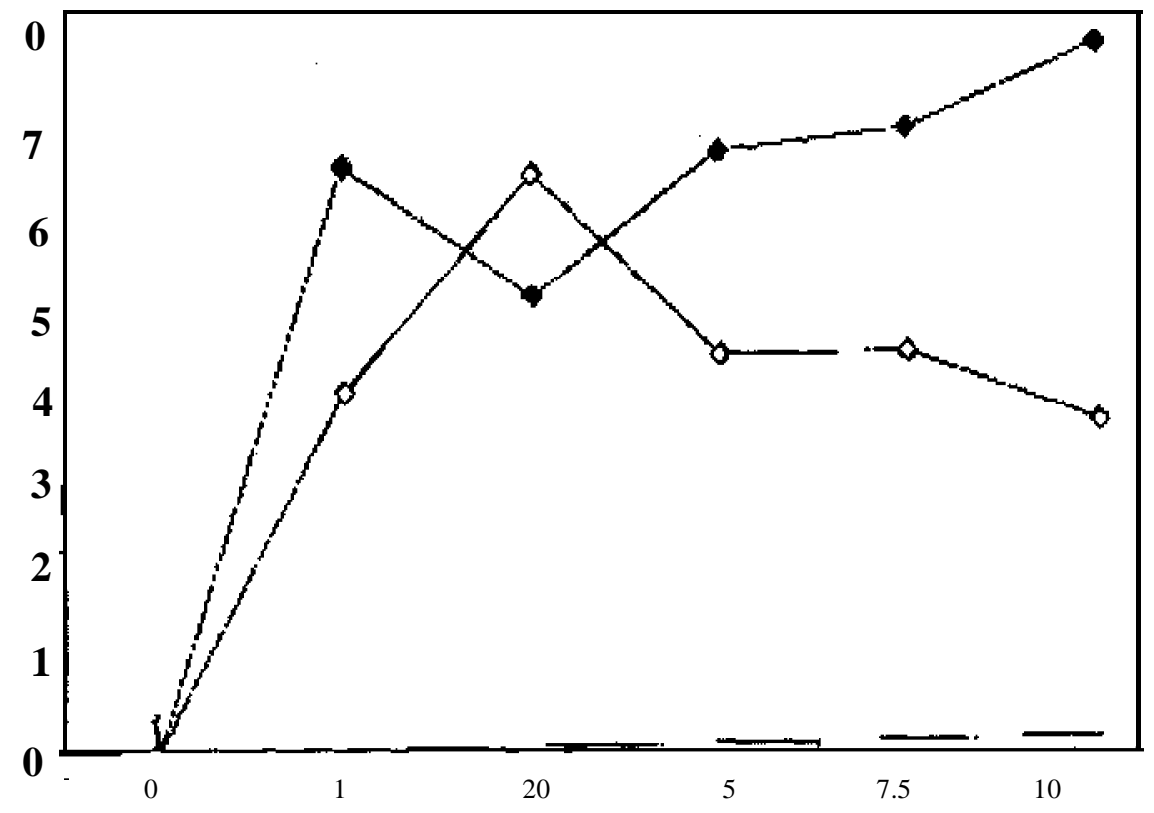

Substrate concentration $(\mathrm{mg} / \mathrm{ml})$

Fig 2. Substrate concentration against enzyme activity of endogenous fraction 


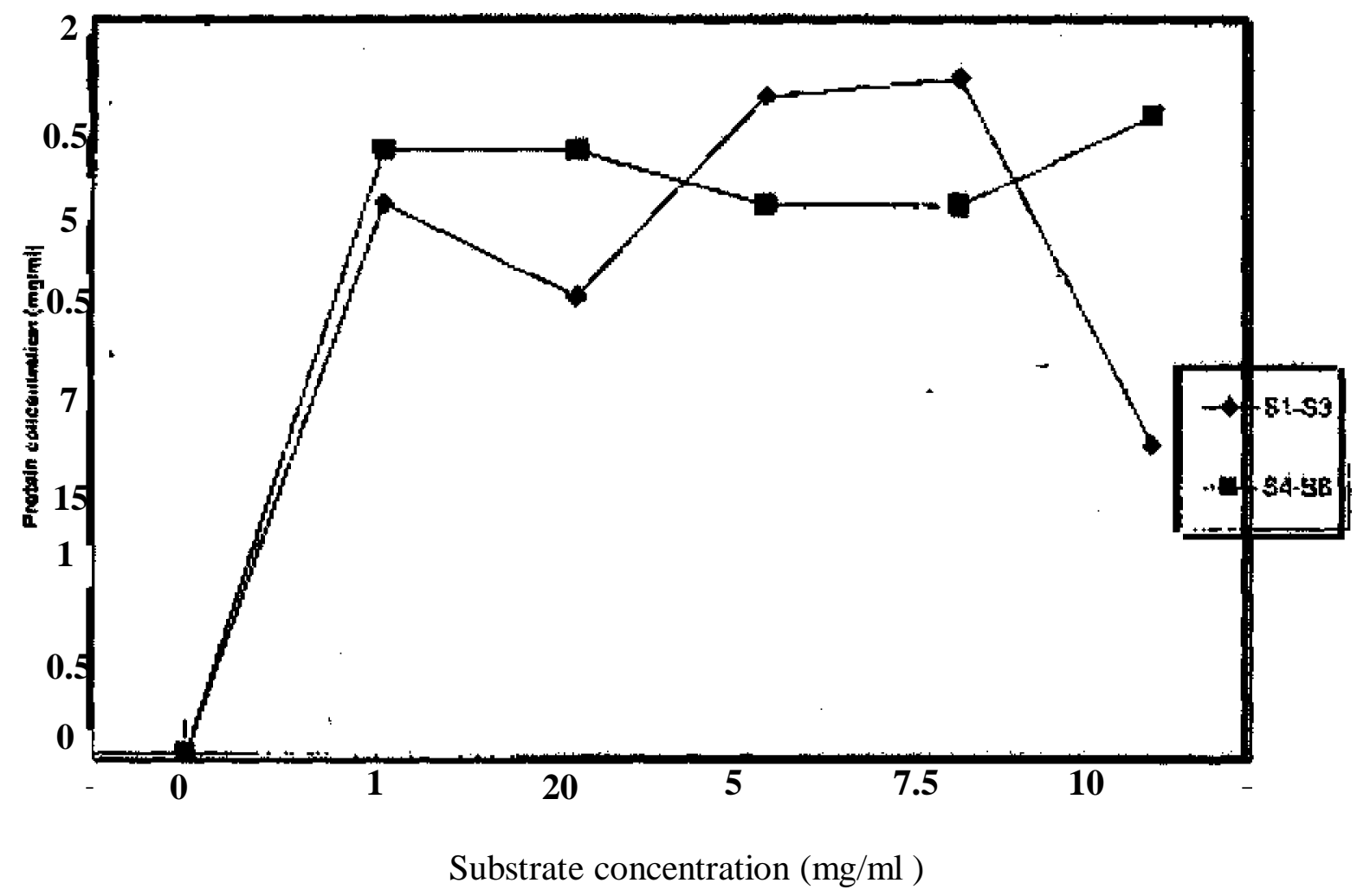

Fig 3. Substrate concentration against protein released in the endogenous friction. 